(RESEARCH ARTICLE)

\title{
Variation of some heavy metal concentrations due to traffic intensity in Prunus cerasifera leaves, seeds and branches
}

\author{
Ozer Genç Cigdem 1, *, Ozturk Ayse 1, Akarsu Hatice ${ }^{2}$ and Abacioglu Ezgi 3 \\ ${ }^{1}$ Kastamonu University, Faculty of Forestry Department of Forestry Engineering, Kastamonu, Turkey. \\ ${ }^{2}$ Düzce University, Institute of Science, Department of Forest Engineering, Düzce, Turkey \\ ${ }^{3}$ Bartın University, Institute of Science, Department of Forest Engineering, Bartın, Turkey.
}

Publication history: Received on 23 September 2019; revised on 11 October 2019; accepted on 15 October 2019

Article DOI: https://doi.org/10.30574/wjarr.2019.3.3.0070

\begin{abstract}
This study aimed that the increasing population and the number of vehicles in the cities have brought air pollution. It has become one of the most important problems of the modern age. Many pollutants emerge from city roads due to exhaust gases, car wheels, vehicles and vehicle wear, and these sources of pollution are affecting the development and health of living things in their environment. Among these pollution factors, heavy metals have a huge important role of air pollution. The heavy metals tend to bioaccumulate and some have toxic effects even at very low concentrations. Therefore, monitoring of the change in heavy metal concentration is extremely important. Plants are used as a biomonitor for determining heavy metal pollution. In this study, it was tried to determine the possibilities of using Prunus cerasifera as biomonitor which is frequently used in landscape studies. So concentrations of $\mathrm{Ba}, \mathrm{Al}, \mathrm{Ca}, \mathrm{Fe}, \mathrm{K}$ and Mg elements were determined by analyzing Prunus cerasifera leaves, seeds and branches collected from some areas including no traffic, mid-intensity, intense traffic. As a result of the study, it was determined that the elements other than K were significantly changed at confidence level of least 95\% on the basis of organelles. When the changes of the elements on the basis of organelle depending on traffic density were examined, it was found that the concentrations of $\mathrm{Ca}$ in leaf, $\mathrm{Ba}$ and $\mathrm{K}$ in seed, $\mathrm{Ba}, \mathrm{Fe}$ and $\mathrm{Mg}$ in branch increased depending on traffic density.
\end{abstract}

Keywords: Prunus cerasifera; Leaves seeds; Branches; Heavy metal; Traffic; Biomonitor

\section{Introduction}

Today, the one of most important problems of the world in general are population growth and the difficulties related to population growth. In addition to the increase in the world population, the increasing number of the population living in urban centers has brought many problems. This process causes destruction of nature, air, water and soil pollution, and deterioration of ecological balance $[1,2,3,4,5]$.

Air pollution is one of the most important of today's problems [6]. It is stated that approximately 6.5 million people die every year in the world due to air pollution [7]. Among the air pollution factors, heavy metals have particular importance because heavy metals do not easily disappear in nature, and they tend to bioaccumulate and some have toxic or carcinogenic effects even at low concentrations [8,9]. Even heavy metals that act as micronutrients can have toxic effects for humans at high concentrations $[10,11]$. Studies show that almost all metals are toxic when taken over a certain amount. Therefore, the determination and monitoring of the concentration of heavy metals in the air is extremely important for the determination of risk zones and risk levels $[12,13,14]$.

Most of the heavy metals are spread to the atmosphere from anthropogenic sources that is, as a result of human activities. In the facilities where various metals are used as raw materials, as a result of heating the mines, various

\footnotetext{
${ }^{*}$ Corresponding author

E-mail address: cozer@kastamonu.edu.ter
} 
heavy metals are spread to the atmosphere. Traffic is also an important source of heavy metals. Exhaust gases of vehicle, wheels, vehicle wear cause to the increasing of concentration of heavy metals in the air. Therefore, heavy metal emissions causing from industrial and traffic activities are among the most important sources of atmospheric pollution $[15,8]$

The change of heavy metal pollution in the atmosphere can be determined by direct and indirect methods. However, bioindicators are one of the most effective methods for detecting air pollution. In addition to being cheap and easy, this method can provide information about the effect of heavy metal concentration on the ecosystem [16, 17]. In this study, the possibilities of using of Prunus cerasifera as biomonitor which is frequently used in landscaping studies were investigated.

\section{Material and methods}

\subsection{Material}

Study has been carried out on Prunus cerasifera samples collected from the city center of Kastamonu. Prunus is a member of the Magnoliopsida class and Rosales and Rosaceae family. The Prunus consists of about 400 trees and shrubs [18]. Plums (Prunus sp.) are well adapted to a wide range of eco-geographical conditions, as shown by the diversity of species in the world [19]. Plum species are mostly found in the temperate zone but are natural in the Northern Hemisphere. Plums have properties that affect their distribution in nature. For example, it has different soil and ecological requirements. Climatic needs of plum species also differ from each other [18]. P. cerasifera requires a mild climate and therefore the sensitivity to frost and cold increases when the fruit is young and during flowering. Therefore, the cultivation of $P$. cerasifera, known to bloom early, is not recommended in areas with frequent winter and spring frosts [18]. Natural populations, viability, temperature tolerance, ripening time vary highly depending on disease resistance; this easily adapts it to various regions. Prunus cerasifera is a deciduous shrub or small tree that can reach a height of 8-10 m. It has sometimes spiny branches, complex, good, upright and bushy structure, with. Young branches are glabrous and shiny [20].

Within the context of present study, Kastamonu city center where the samples have been collected and selected as an area where traffic dense, is a region where four lane highway with two lanes in each direction is located. In this region, generally there has been a heavy traffic during the day. The areas where traffic is less dense is located on the main road route but the areas where traffic is free-flowing is located outside of the city center. There is a two lane road located in this region, traffic is free-flowing and traffic density is much lower in contrast to city center. Kastamonu University campus area has been selected as an area where there is no traffic and the points where there is no highway within the radius of at least $50 \mathrm{~m}$ in the campus have been selected and samples have been collected from such places. Leaf, seed and branch samples were collected from the same branch towards the end of the 2018 vegetation season, in late August. Samples were packed - labeled and brought to the laboratory.

\subsection{Method}

The labeled samples that were brought to laboratory were subjected to separation process by laying on top of the cartons. Leaves, branches and seeds were separated, classified. Then the branches were broken and smashed to easily dry, and the seeds were smashed. The seeds were smashed with marble pieces, no metal tools were used. Prepared samples were placed into glass petri dish and re-labeled. The samples were kept for 15 days until they became roomdry, during this process laboratory was ventilated on a daily basis. Air-dried samples were left in a drying oven at 45 ${ }^{\circ} \mathrm{C}$ for one week to dry completely.

At the next phase, plant samples were ground into a powder and weighted of $0,5 \mathrm{~g}$ and placed in tubes designed for microwave. $10 \mathrm{ml}$ of $65 \% \mathrm{HNO}_{3}$ were added to the samples. Fume hood was used during this processes. Prepared samples were burned at $180 \stackrel{\circ}{\circ}$ for 20 minutes at 280 PSI pressure in the microwave. After processes were completed, tubes were removed from the microwave and they were left to cool. Deionized water was added to cooled samples and thus making it to $50 \mathrm{ml}$. After prepared samples were filtered through a filter paper, they were tested with ICPOES at optimum wavelengths.

Obtained data were analyzed using the SPSS software. Using variance analysis, at a confidence level of at least \%95 Duncan's test was applied to the values and homogeneous groups were obtained. The data were simplified, tabulated and interpreted. 


\section{Findings}

\subsection{Change in heavy metal concentration on the basis of organ}

In mentioned samples, the change in heavy metal concentration has been determined, variance analysis and Duncan's test was applied to data and obtained mean values, obtained $F$ value through variance analysis, significance level and the homogeneous groups resulted from Duncan's test were presented in Table 1.

Table 1 Change in heavy metal concentration on the basis of organ

\begin{tabular}{llllll}
\hline Elements & Leaf & Seed & Branch & F Value & Error \\
\hline $\mathrm{Ba}$ & $21,467 \mathrm{a}$ & $98,556 \mathrm{~b}$ & $11,256 \mathrm{a}$ & 40,501 &, 000 \\
$\mathrm{Al}$ & $261,67 \mathrm{a}$ & $1676,56 \mathrm{~b}$ & $43,33 \mathrm{a}$ & 23,214 &, 000 \\
$\mathrm{Ca}$ & $1467,44 \mathrm{a}$ & $4192,00 \mathrm{~b}$ & $6731,33 \mathrm{c}$ & 228,852 &, 000 \\
$\mathrm{Fe}$ & $276,33 \mathrm{a}$ & $650,33 \mathrm{~b}$ & $61,22 \mathrm{a}$ & 8,098 &, 002 \\
$\mathrm{~K}$ & 12216,33 & 9152,22 & 5235,56 & 3,397 &, 050 \\
$\mathrm{Mg}$ & $4996,11 \mathrm{a}$ & $11859,89 \mathrm{~b}$ & $9120,22 \mathrm{~b}$ & 12,355 &, 000 \\
\hline
\end{tabular}

When Table 1 is examined, it is seen that only the $\mathrm{K}$ concentration on basis of organ is not statistically significant at least 95\% confidence level, the change in Fe concentration on basis of organ is statistically significant at a confidence level. of $99 \%$ and other elements at a confidence level of 99.9\%. According to Duncan test results, all the concentrations obtained in the leaf were in the first homogeneous groups and it is remarkable that the highest concentrations were generally obtained in seed.

\subsection{Change of heavy metal concentration in leaves depending on traffic density}

In mentioned leaves samples, the change of heavy metal concentration depending on traffic density has been determined, variance analysis and Duncan's test was applied to data and obtained mean values, obtained F value through variance analysis, significance level and the homogeneous groups resulted from Duncan's test were presented in Table 2.

Table 2 Change of heavy metal concentration in leaves depending on traffic density

\begin{tabular}{llllll}
\hline Elements & No traffic & Less dense traffic & Dense traffic & F value & Error \\
\hline $\mathrm{Ba}$ & $31,767 \mathrm{c}$ & $15,733 \mathrm{a}$ & $16,900 \mathrm{~b}$ & 4315,020 &, 000 \\
$\mathrm{Al}$ & $339,33 \mathrm{c}$ & $286,33 \mathrm{~b}$ & $159,33 \mathrm{a}$ & 25669,000 &, 000 \\
$\mathrm{Ca}$ & $1463,33 \mathrm{a}$ & $1465,00 \mathrm{a}$ & $1474,00 \mathrm{~b}$ & 40,409 &, 000 \\
$\mathrm{Fe}$ & $284,00 \mathrm{~b}$ & $334,33 \mathrm{c}$ & $210,67 \mathrm{a}$ & 13052,625 &, 000 \\
$\mathrm{~K}$ & $7797,67 \mathrm{a}$ & $14204,67 \mathrm{~b}$ & $14646,67 \mathrm{c}$ & 9570,840 &, 000 \\
$\mathrm{Mg}$ & $5001,00 \mathrm{c}$ & $4993,00 \mathrm{a}$ & $4994,33 \mathrm{~b}$ & 496,000 &, 000 \\
\hline
\end{tabular}

When the results of variance analysis have been analyzed, it is seen that change of of all elements in leaves samples depending on traffic density is statistically significant at a confidence level of $99.9 \%$. According to the average values and Duncan test results, it is quite difficult to say that there is a linear relationship between the traffic density and the concentrations of the mentioned elements.

\subsection{Change of heavy metal concentration in seeds depending on traffic density}

In mentioned leaves samples, the change of heavy metal concentration depending on traffic density has been determined, variance analysis and Duncan's test was applied to data and obtained mean values, obtained F value through variance analysis, significance level and the homogeneous groups resulted from Duncan's test were presented in Table 3. 
Table 3 Change of heavy metal concentration in seeds depending on traffic density

\begin{tabular}{llllll}
\hline Elements & No traffic & Less dense traffic & Dense traffic & F value & Error \\
\hline $\mathrm{Ba}$ & $51,33 \mathrm{a}$ & $108,67 \mathrm{~b}$ & $135,67 \mathrm{c}$ & 62,990 &, 000 \\
$\mathrm{Al}$ & $1885,00 \mathrm{~b}$ & $2656,67 \mathrm{c}$ & $488,00 \mathrm{a}$ & 2006,018 &, 000 \\
$\mathrm{Ca}$ & $4714,33 \mathrm{~b}$ & $2999,67 \mathrm{a}$ & $4862,00 \mathrm{c}$ & 3648,440 &, 000 \\
$\mathrm{Fe}$ & $1363,00 \mathrm{c}$ & $201,67 \mathrm{a}$ & $386,33 \mathrm{~b}$ & 3563,211 &, 000 \\
$\mathrm{~K}$ & $2403,67 \mathrm{a}$ & $21270,67 \mathrm{c}$ & $3782,33 \mathrm{~b}$ & 291440,082 &, 000 \\
$\mathrm{Mg}$ & $9293,00 \mathrm{~b}$ & $7732,67 \mathrm{a}$ & $18554,00 \mathrm{c}$ & 39393,616 &, 000 \\
\hline
\end{tabular}

When the results of variance analysis have been analyzed, it is seen that change of of all elements in seeds samples depending on traffic density is statistically significant at a confidence level of $99.9 \%$. According to the average values and Duncan test results, it is difficult to say that concentrations other than Ba concentration vary depending on traffic density.

\subsection{Change of heavy metal concentration in branches depending on traffic density}

In mentioned branches samples, the change of heavy metal concentration depending on traffic density has been determined, variance analysis and Duncan's test was applied to data and obtained mean values, obtained F value through variance analysis, significance level and the homogeneous groups resulted from Duncan's test were presented in Table 4.

Table 4 Change of heavy metal concentration in branches depending on traffic density

\begin{tabular}{llllll}
\hline Elements & No traffic & Less dense traffic & Dense traffic & F value & Error \\
\hline $\mathrm{Ba}$ & $10,233 \mathrm{a}$ & $10,733 \mathrm{~b}$ & $12,800 \mathrm{c}$ & 2499,500 &, 000 \\
$\mathrm{Al}$ & $62,67 \mathrm{c}$ & $21,00 \mathrm{a}$ & $46,33 \mathrm{~b}$ & 5950,500 &, 000 \\
$\mathrm{Ca}$ & $6843,33 \mathrm{c}$ & $6765,33 \mathrm{~b}$ & $6585,33 \mathrm{a}$ & 3425,478 &, 000 \\
$\mathrm{Fe}$ & $31,00 \mathrm{a}$ & $49,67 \mathrm{~b}$ & $103,00 \mathrm{c}$ & 37696,000 &, 000 \\
$\mathrm{~K}$ & $7316,67 \mathrm{c}$ & $5280,67 \mathrm{~b}$ & $3109,33 \mathrm{a}$ & 42116,763 &, 000 \\
$\mathrm{Mg}$ & $8586,67 \mathrm{a}$ & $8796,33 \mathrm{~b}$ & $9977,67 \mathrm{c}$ & 2390,923 &, 000 \\
\hline
\end{tabular}

When the results of variance analysis have been analyzed, it is seen that change of of all elements in branch samples depending on traffic density is statistically significant at a confidence level of $99.9 \%$. According to average values and Duncan test results, concentration of $\mathrm{Ba}, \mathrm{Fe}$ and $\mathrm{Mg}$ elements increased with traffic density.

\section{Discussion}

In this study, it was found that all of the mentioned elements except K were statistically significant at confidence level of least $95 \%$ and in general, the lowest values were obtained in the leaf and the highest values were obtained in the seed. In numerous studies conducted to date have shown that heavy metal concentrations vary significantly on organ basis. Mossi (2018) stated that the concentrations of $\mathrm{Cu}, \mathrm{Ni}, \mathrm{Pb}, \mathrm{Cd}$ and $\mathrm{Ca}$ in the mentioned plants were higher in the branches than in the leaves, whereas Mn concentration was higher in the leaves than the branches. [21]. Sevik et al. (2019a) states that the concentrations of heavy metals in organs are different on the basis of species [22]. For example, he stated that the highest Ni concentration in Prunus cerasifera is obtained in seed, whereas highest Ni concentration in Aesculus hippocastanum, Tilia tomentosa and Fraxinus excelsior is obtained in leaves. And there is no statistically significant difference between organs in Acer platanoides.

In studies related to heavy metals, the change of heavy metal concentrations depending on the organ is often the subject of studies. differences between organs was determined in leaf and branch [21], bark and wood [14], leaf, seed 
and branch [22], leaf and branch [23, 24] leaf, branch and fruit [2], leaf, branch and seed [25] inner bark, outer bark and wood [10]. In these studies, it has been shown that heavy metal concentrations significantly change on organ basis. The change of heavy metals on the organ, is in relation to the structure of the plant and the organ as well as the structure of the heavy metal, the environmental conditions and the interaction between all of them. Therefore, it is a complex and not fully solved mechanism. Also the information on this subject is limited. [15,2, 26].

In the scope of the study $\mathrm{Ba}, \mathrm{Al}, \mathrm{Ca}, \mathrm{Fe}, \mathrm{K}$ and $\mathrm{Mg}$ elements were evaluated. Studies conducted to date have generally focused on elements such as $\mathrm{Pb}, \mathrm{Ni}, \mathrm{Co}, \mathrm{Cd}, \mathrm{Cr}, \mathrm{Cn}$ and $\mathrm{Cu}$ due to their potential hazards and high toxicity [2,16,17]. However, the mentioned elements to this study can be extremely dangerous for human health. Fe of these elements can cause death for 6 years' children or younger if accidentally overdosed with food. When Al is taken in high amounts with foods, it results in different disease such as phosphorus metabolism, muscle weakness, growth stagnation, microsciatic anemia, Vitamin-D resistant osteodystrophy, rickets, memory weakness, speech and voice impairment, brain damage advancement, Alzheimer. In addition, excessive aluminum uptake causes cardio-toxic A, embryo-toxic and teratogenic effects [27].

Excess Ca causes kidney stones, calcification muscle weakness in the human body. Excess K may cause problems such as vomiting, fatigue, heart and brain disorders, and even sudden cardiac arrest. Excess Al in human damages the nervous system. Excess $\mathrm{P}$ can firstly disrupt the balance of $\mathrm{Ca}$ in the body. Then can reduce the strength of bones and can cause high blood pressure [28]. As seen, the mentioned elements to the study are extremely important for human health and may even cause death. Therefore, numerous studies have been carried out to determine the plants and organs that can be used as biomonitor at monitoring of concentration of elements in atmosphere $[13,14,22,29,10]$.

There are many factors affecting the penetration and accumulation of heavy metals in air into plant. Studies conducted to date have shown that the diffusion of heavy metals in the atmosphere and entry into the plant is a very complex mechanism. [15,21]. The heavy metal accumulation potential of the plants grown in the same environment is shaped depending on the plant species and plant organ, as well as the structure of organ and metal, environmental conditions $[15,11]$.

In addition to these factors, there are also other factors likely to affect the concentration of heavy metals. For example, the plant structure and its characteristics arise from the interaction of genetic structure and environmental conditions. It is known that each genetic structure can differently react to the same environmental conditions $[30,31,32,33]$. For example, different clones of the same species were found to have different resistance to water and frost stress. [34,35]. Consequently, the components of these factors are likely to shape the uptake of heavy metal in the plant. Studies reveal that many phenological, morphological and anatomical characters are affected significantly by these factors [36, 37, 28 39,29]

Heavy metal uptake and accumulation in plants are closely related to plant metabolism [15, 22,29]. Therefore it is possible for many factors to affect considerably plant metabolites such as stress level $[40,13,14]$ origin of plant [36], application of hormones $[41,42,43,44,45]$, to absorption of heavy metal in plants.

As a result, the change in heavy metal concentration in plants is the result of a complex mechanism due to the interaction of many factors. However, this mechanism is not fully solved. Information on the absorption of heavy metals from above-ground organs is very limited $[15,21]$. Therefore, the studies on the subject should be diversified and increased.

\section{Conclusion}

As a result of the study, it was found that all of the mentioned elements except $\mathrm{K}$ were statistically significant at confidence level of least $95 \%$ and when the changes of the elements on the basis of organelle depending on traffic density were examined, it was found that the concentrations of $\mathrm{Ca}$ in leaf, $\mathrm{Ba}$ and $\mathrm{K}$ in seed, $\mathrm{Ba}, \mathrm{Fe}$ and $\mathrm{Mg}$ in branch increased depending on traffic density.

\section{Compliance with ethical standards}

\section{Acknowledgments}

Special thanks to Dr. Hakan SEVİK for him helps in the study. 


\section{Disclosure of conflict of interest}

The author declares no conflict of interest.

\section{References}

[1] Mutlu E, Demir T, Yanık T and Anca Sutan N. (2016). Determination of environmentally relevant water quality parameters in Serefiye Dam-Turkey. Fresenius Environ Bull, 25(12), 5812-5818.

[2] Ozel HU, Ozel HB, Cetin M, Sevik H, Gemici BT and Varol T. (2019). Base alteration of some heavy metal concentrations on local and seasonal in Bartin River. Environmental monitoring and assessment, 191(9), 594.

[3] Bayraktar OY. (2019). The possibility of fly ash and blast furnace slag disposal by using these environmental wastes as substitutes in portland cement. Environmental monitoring and assessment, 191(9), 560.

[4] Bayraktar OY, Citoglu Saglam G, Belgin CM and Cetin M. (2019a). Investigation of The Mechanical Properties of Marble Dust and Silica Fume Substituted Portland Cement Samples Under High Temperature Effect, Fresenius Environmental Bulletin, 28(5), 3865-3875.

[5] Bayraktar OY, Citoğlu Saglam G, Belgin CM and Cetin M. (2019b). Investigation of Effect of Brick Dust and Silica Fume on The Properties of Portland Cement Mortar, Fresenius Environmental Bulletin, (In Press).

[6] Cetin M, Onac AK, Sevik H and Sen B. (2019). Temporal and regional change of some air pollution parameters in Bursa. Air Quality, Atmosphere \& Health, 12(3), 311-316.

[7] Cetin M, Sevik H and Isinkaralar K. (2017). Changes in the Particulate Matter and CO2 Concentrations Based on the Time and Weather Conditions: The Case of Kastamonu. Oxidation Communications, 40 (1-II), 477-485.

[8] Turkyilmaz A, Sevik H and Cetin M. (2018a). The use of perennial needles as bio-monitors for recently accumulated heavy metals. Landsc Ecol Eng, 14(1), 115-120.

[9] Turkyilmaz A, Cetin M, Sevik H, Isinkaralar K and Saleh EAA. (2018b). Variation of heavy metal accumulation in certain landscaping plants due to traffic density. Environment, Development and Sustainability, 1-14.

[10] Akarsu H. (2019). Determination of heavy metal accumulation in atmosphere by being aid of annual rings. Kastamonu University Institute of Science, Msc. Thesis. Kastamonu.

[11] Özel S. (2019). The Variation of Heavy Metal Accumulation in Some Fruit Tree Organelles Due to Traffic Density. Kastamonu University Graduate School of Natural and Applied Sciences Department of Sustainable Agriculture and Natural Plant Resources. MSc Thesis.

[12] Ozel HB, Ozel HU and Varol T. (2015). Using Leaves of Oriental Plane (Platanus orientalis L.) to Determine the Effects of Heavy Metal Pollution Caused by Vehicles. Pol. J. Environ. Stud., 24 (6), 2569-2575.

[13] Turkyilmaz A, Sevik H, Cetin M and Ahmaida Saleh EA. (2018c). Changes in heavy metal accumulation depending on traffic density in some landscape plants. Pol J Environ Stud., 27(5), 2277-2284.

[14] Turkyilmaz A, Sevik H, Isinkaralar K and Cetin M. (2018d). Using Acer platanoides annual rings to monitor the amount of heavy metals accumulated in air. Environ Monit Assess, 190, 578.

[15] Shahid M, Dumat C, Khalida S, Schreck E, Xiong T and Nabeel NK. (2017). Foliar heavy metal uptake, toxicity and detoxification in plants: A comparison of foliar and root metal uptake. Journal of Hazardous Materials, 325, 3658.

[16] Aricak B, Cetin M, Erdem R, Sevik H and Cometen H. (2019a). The change of some heavy metal concentrations in Scotch pine (Pinus sylvestris) depending on traffic density, organelle and washing, Applied Ecology and Environmental Research, 17(3), 6723-6734.

[17] Aricak B, Cetin M, Erdem R, Sevik H and Cometen H. (2019b). The usability of Scotch pine (Pinus sylvestris) as a biomonitor for traffic originated heavy metal concentrations in Turkey, Polish Journal of Environmental Studies (In Press).

[18] Çakır G. (2018). Molecular Genetıc Analyses in Turkısh Plum (Prunus cerasifera). İzmir, Türkiye.

[19] Sarıdaş MA KE, Zarıfıkhosroshahı M, Bozhaydar O and Kargı SP. (2016). Quality Traits of Green Plums (Prunus cerasifera Ehrh.) At Different Maturity Stages. Turkish Journal of Agriculture And Forestry, 655-663. 
[20] Popescu I and Caudullo G. (2019). Prunus cerasifera İn Europe: Distribution, Habitat, Usage and Threats. Tree Atlas, 142.

[21] Mossi MMM. (2018). Determination of Heavy Metal Accumulation in The Some of Landscape Plants For Shrub Forms Kastamonu University Institute of Science Department of Forest Engineering. PhD. Thesis

[22] Sevik H, Cetin M, Ozel HB and Pinar B. (2019a). Determining toxic metal concentration changes in landscaping plants based on some factors. Air Quality, Atmosphere \& Health, 12(8), 983-991.

[23] Elfantazi MFM, Aricak B and Baba FAM. (2018a). Changes in Concentration of Some Heavy Metals in Leaves And Branches of Acer Pseudoplatanus Due to Traffic Density. International Journal of Trend in Research and Development, 5(2), 704-707.

[24] Elfantazi MFM, Aricak B and Ozer Genc C. (2018b). Concentrations in Morus Alba L. Leaves and Branches Due To Traffic Density. International Journal of Current Research, 10(05), 68904-68907.

[25] Pinar B. (2019). The Variation of Heavy Metal Accumulation in Some Landscape Plants Due to Traffic Density. Kastamonu University Graduate School of Natural and Applied Sciences Department of Sustainable Agriculture and Natural Plant Resources. MSc Thesis.

[26] Yiğit N. (2019). Determination of Heavy Metal Accumulation in Air Through Annual Rings: The Case of Malus floribunda Species, Applied Ecology and Environmental Research, 17(2), 2755-2764.

[27] Mor F, Kurşun Ö and Erdoğan N. (2009). Effects of Heavy Metals Residues On Human Health. Uludag Univ. J. Fac. Vet. Med, 59-65.

[28] Kobya Y and Yeşilkanat CM. (2017). Doğu Karadeniz Bölgesindeki Bazı Doğal Kaynak Sularının Elemental Analizi ve Haritalandırılması ile Çevre ve İnsan Sağlığına Etkilerinin Araştırılması. Doğal Afetler ve Çevre Dergisi, 28-38.

[29] Sevik H, Ozel HB, Cetin M, Özel HU and Erdem T. (2019b). Determination of changes in heavy metal accumulation depending on plant species, plant organism, and traffic density in some landscape plants. Air Quality, Atmosphere \& Health, 1-7.

[30] Hrivnák M, Paule L, Krajmerová D, Kulac S, Sevik H, Turna I, Tvauri I and Gömöry D. (2017). Genetic variation in tertiary relics: the case of eastern-Mediterranean Abies (Pinaceae). Ecol Evol, 7(23), 10018-10030.

[31] Yucedag C, Ozel HB, Cetin M and Sevik H. (2019). Variability in morphological traits of seedlings from five Euonymus japonicus cultivars. Environmental Monitoring and Assessment, 191, 285.

[32] Sevik H, Cetin M, Ozturk A, Yigit N and Karakus 0. (2019c). Changes in micromorphological characters of Platanus orientalis L. leaves in Turkey. Applied Ecology and Environmental Research, 17(3), 5909-5921.

[33] Yiğit N, Çetin M and Şevik H. (2018). The Change in Some Leaf Micromorphological Characters of Prunus laurocerasus L. Species by Their Habitat. Turkish Journal of Agriculture-Food Science and Technology, 6(11), 1517-1521.

[34] Topacoglu O, Sevik H and Akkuzu E. (2016a). Effects of Water Stress on Germination of Pinus nigra Arnold. Seeds, Pak. J. Bot., 48(2), 447.

[35] Sevik H and Karaca U. (2016). Determining the Resistances of Some Plant Species to Frost Stress Through Ion Leakage Method. Feb-fresenius environmental bulletin, 25(8), 2745-2750.

[36] Sevik H and Topacoglu 0. (2015). Variation and Inheritance Pattern in Cone and Seed Characteristics of Scots pine (Pinus sylvestris L.) for Evaluation of Genetic Diversity, Journal of Environmental Biology, 36(5), 11251130.

[37] Yigit N, Sevik H, Cetin M and Gul L. (2016). Clonal Variation in Chemical Wood Characteristics in Hanönü (Kastamonu) Günlüburun Black Pine (Pinus nigra Arnold. subsp. pallasiana (Lamb.) Holmboe) Seed Orchard. Journal of Sustainable Forestry, 35(7), 515-526.

[38] Cetin M., Sevik H and Yigit N. (2018a). Climate type-related changes in the leaf micromorphological characters of certain landscape plants. Environmental monitoring and assessment, 190(7), 404.

[39] Cetin M, Sevik H, Yigit N, Ozel HB, Aricak B and Varol T. (2018b). The variable of leaf micromorphogical characters on grown in distinct climate conditions in some landscape plants. Fresenius Environmental.

[40] Sevik H and Cetin M. (2015). Effects of water stress on seed germination for select landscape plants. Pol J Environ Stud., 24(2), 689-693. 
[41] Guney K, Cetin M, Sevik H and Guney KB. (2016a). Effects of some hormone applications on germination and morphological characters of endangered plant species Lilium artvinense L. Seeds, New Challenges in Seed Biology-Basic and Translational Research Driving Seed Technology, Dr. Susana Araújo. InTech, 4, 97112.Bulletin, 27(5), 3206-3211.

[42] Guney K, Cetin M, Sevik H and Guney KB. (2016b). Influence of Germination Percentage and Morphological Properties of Some Hormones Practice on Lilium martagon L. Seeds. Oxidation Communications, 39 (1-II), 466474.

[43] Sevik H, Güney K, Topaçoğlu $O$ and Ünal C. (2015). The influences of rooting media and hormone applications on rooting percentage and some root characters in Schefflera arboricola. International Journal of Pharmaceutical Science Invention, 4(2), 25-29.

[44] Topacoglu O, Sevik H, Guney K, Unal C, Akkuzu E and Sivacioglu A. (2016b). Effect of rooting hormones on the rooting capability of Ficus benjamina L. cuttings. Šumarski list, 140(1-2), 39-44.

[45] Guney K, Cetin M, Guney KB and Melekoglu A. (2017). The Effects of Some Hormone Applications on Lilium martagon L. Germination and Morpholgical Characters. Polish Journal of Environmental Studies, 26(6).

\section{How to cite this article}

Ozer Genç C, Ozturk A, Akarsu H and Abacioglu E. (2019). Variation of some heavy metal concentrations due to traffic intensity in Prunus cerasifera leaves, seeds and branches. World Journal of Advanced Research and Reviews, 3(3), 1926. 